International Business Management 6(3): 317-324, 2012

ISSN: $1993-5250$

(C) Medwell Journals, 2012

\title{
E-Commerce and Consumer Protection in Iran: A Legal Framework
}

\author{
Parviz Bagheri and K.H. Hassan \\ Faculty of Law, University Kebangsaan Malaysia, Malaysia
}

\begin{abstract}
While Iran is transforming itself into a forerunner in the ICT arena, its laws must be relevant to the transition. Not only should the laws be applicable to innovations in E-commerce but they should also be on par with and sensitive to the legal developments taking place worldwide including consumer protection. Against that background, the researchers discuss the development of electronic commerce and consumer protection in Iran from the legal perspective. A question arises: whether Iran has a proper legal framework for E-commerce and consumer protection? Electronic Commerce Law 2004 and Consumer Rights Protection Act (CRPA) 2009 are the laws which inspire hopes to solve legal problems of business conduct in virtual era. The CRPA 2009, furthermore is only supplementary in nature and is not a main act and the lack of relatedness among these laws reduces their efficacy in protecting consumer rights.
\end{abstract}

Key words: Iran, E-commerce, consumer, law, business, Malaysia

\section{INTRODUCTION}

As almost all aspects of social life are guided by laws of some form the role of law in E-commerce consumer protection has been a topic of great interest. As Ewan stated, the rules of law have not grown in a vacuum and cannot be developed in a vacuum. It is the real world and the changing expectations which drive growth and as a result develop the rules of law (McKendrick and Gullifer, 2000). Consumer issues have been at the forefront of legal attention domestically. In the United States, many of the principal consumer protection statutes were enacted during the 1960 and 1970's (Overby, 2001). The law plays a crucial role in society because it is premised on social life (Brian, 2006; Chand, 1999; Freeman et al., 2008). However, whether the existing laws in Iran relate to Iranian society is debatable. Chand (1999) states that the modern state currently is choked with laws, by laws, precedents, rules, notifications, international conventions, treaties and agreements. However, today's laws although elaborate and touching every aspect of life may not represent the real phenomenon. Today, law is viewed as a collection of precepts, ideas and techniques. If the laws and regulations of a nation want to keep pace with technology advancements and consider consumers' rights, they must reflect the latest developments, especially in the field of commerce. It is against this background that the researcher examines Iranian laws governing E-commerce and consumer protection.

There are existing laws and legislation in the area of E-commerce and consumer protection in Iran, namely the Civil Code (CC in 1936), Commercial Code in 1930 ,
Electronic Commerce Law (ECL in 2004), Consumer Rights Protection Act (CRPA in 2009), Car (Vehicle) Consumer Rights Act (CCRA in 2008), Computer Crimes Act and Penal Code. The role and evolution of these laws are analysed to identify their overall inadequacies and the reasons for their occasionally slow progression in adjusting to E-commerce and providing legal protection for the consumers in Iran.

\section{THE LEGISLATION}

While Iran is transforming itself into a forerunner in the ICT arena, its laws must be relevant to the transition. Not only should the laws be applicable to innovations in E-commerce but they should also be on par with and sensitive to the legal developments taking place worldwide including consumer protection.

\section{ONLINE TRANSACTIONS AND CONSUMER'S LEGAL PROTECTION}

The question of whether consumer transactions ought to be regulated at all or at least treated differently from other types of contracts, especially when executed online provides a departure point for an inquiry into consumer protection issues (Overby, 2001). Legal commentators have debated how the law should provide protection to consumers before, during and after executing an E-commerce contract (Weatherhill, 2005). Although, it seems that consumer protection in Iran gained statutory significance and prominence with the enactment of the Consumer Rights Protection Act

Corresponding Author: Parviz Bagheri, Faculty of Law, University Kebangsaan Malaysia, Malaysia 
(CRPA) in 2009, it is irrelevant to consumer protection in E-commerce transactions. However, consumers who buy goods and services via the internet could rely on Chapter III, Part 1, Section 1 of the Iranian Electronic Commerce Law of 2004. This section of the act expressly protects consumers in trade transactions executed by electronic means. Even though (CRPA in 2009) is mostly comprehensive in its terms contractual issues need attention to provide consumer protection in E-commerce contracts.

The Iranian Civil Code in 1936 and other civil law principles normally govern contractual issues but they are not sufficient to protect consumers in E-commerce or online transactions. Because the Civil Code 1936 is old, the contractual principles and doctrines incorporated into the code need to be re-evaluated. Old doctrines and principles are poorly suited to the technicalities of contract formation through the internet. However, the code treats all contracts as generally the same so an E-commerce transaction is not seen as inherently different from a transaction taking place through other means. The Civil Code in 1936 has remained unchanged despite the fundamental changes to the character of commerce including E-commerce.

It is important to reconcile the law with technology, especially with the ever-evolving internet technology. A pro-commerce attitude toward the law and technology in Iran with the welfare of the society in mind (i.e., consumer protection) is crucial to Iran's reaching the forefront of E-commerce (Moghadasi, 2008).

In the United States when Llewellyn (1939) fought to replace the old uniform commercial code, he stated that it's time to unhorse the law that was based on economies existing before the mercantile or industrial age. Therefore, it is also timely to unhorse the existing laws in Iran, especially to protect the consumer in E-commerce or online transactions.

The business-to-consumer category primarily relates to electronic retailing which has expanded significantly with the introduction of the internet. However, the internet will not be used to its fullest commercial potential if providers and consumers cannot be confident that their electronic agreements are valid and enforceable (Forder and Quirk, 1995). One way of achieving this confidence is through the proper laws. Iran is not without laws to regulate E-commerce contracts and provide consumer protection. Nevertheless, some of these laws such as Civil Code in 1936 and Commercial Code in 1930 were enacted long ago for different objectives and do not address many issues arising in E-commerce. For example,
Article 975 of the civil code nullifies any contract that is against the public order or good faith. The Act of Car Consumers Rights No: 525/49525 (2008) also contains some suitable terms, especially regarding consumer's rights in the event of a product defect and the liability of the producers to remove the defects.

Electronic Commerce Law 2004 and Consumer Rights Protection Act (CRPA) from another hand are the laws which inspire hopes to solve legal problems of business conduct in virtual era. The CRPA in 2009 , furthermore is only supplementary in nature and is not a main act and the lack of relatedness among these laws reduces their efficacy in protecting consumer rights. A rule-based approach generally ensures the certainty and protection of the weaker party but unreasonably limits the functioning of a jurisdiction clause in E-consumer contracts.

Laws in Iran are made according to the rule-based approach or civil law. In other words, unlike their discretion-based counterparts, they set up provisions that clearly distinguish consumer contracts from other types of contracts and define different rules regarding the effect and application of the laws to protect consumers. As a whole, legislators should enact suitable new laws and reform existing laws and legislation to protect the consumers incorporating the following:

- $\quad$ Right to be protected against the marketing of goods and services that are hazardous to life and property

- Right to be informed about the quality, quantity, potency, purity, standard and price of goods or services before, during and after the transaction to protect the consumer against unfair trade practices

- Right to be assured wherever possible access to a variety of goods and services at competitive prices

- Right to be heard and to be assured that consumers' interests will receive due consideration in appropriate forums

- $\quad$ Right to seek redress against unfair trade practices and unscrupulous exploitation of consumers

- Right to consumer education

- Right to effective cooperation in establishing the standards of the products and other related acts regarding consumer protection and

- Right to test the goods prior to purchase

The nature of open Internet networks during electronic transactions creates a number of threats including privacy and security violations. As Lynch (1997) states, consumers encounter a number of questionable issues when shopping online: 
What if a product ordered through the internet never arrives? Is a credit card open to misuse once its number gets into cyber space? Will products prove to be less safe than those bought in person? Moreover, specific rules about product liability may have to be re evaluated for E-commerce

Regarding most of the before mentioned consumer protection rights, Iranian laws are inadequate and sometimes, there is no law or legislation pertaining to a given aspect of online transactions.

\section{CONSUMER PROTECTION: RELEVANT LEGISLATION}

Globally as with most areas of law, there is no consensus on the underlying basis for regulating consumer transactions or on the goals of consumer law (Overby, 2001). One way to evaluate a field's claims is to look at its history (Ponser, 2003). The progression of the law should mirror the nation's development. The rule of law should reflect the progress of the society and must answer the need for certainty, predictability, order and safety (Kohl, 1999). The laws should reflect the progress of the society instead of mulling with uncertainties and lacunas (Ramsay, 2007). The electronic consumer's (E-consumer's) weaker position can be protected by strict prerequisites. Consumer protection laws must aim to provide consumers with the minimum prerequisites for every commercial transaction. They must be designed to protect the interests of consumers in trade and commerce whether electronic or traditional. In B2C transactions, consumers cannot read or correctly evaluate the contents of the contracts prior to and at the time of their formation, thus vendors can structure biased contractual terms. A key consumer issue is the existence and application of consumer protection laws to E-commerce transactions, particularly those transactions that occur across national borders.

The growth in the consumer economy, globalisation, innovations in technology and communications and efforts to modernise Iran's laws have contributed to renewed concern over legal regulation of consumer transactions. In Iran, this revival of interest in consumer protection has built upon and perhaps reinterpreted issues related to E-commerce. According to the most basic concepts of law and economics, both contracting parties are assumed to accept only efficient contracts that maximise their utility (Gillette, 2005). The contractual issues in Iran are governed by the Civil Code in 1936. As indicated before, this legislation provides general principles of contract and is one of the best laws to solve contractual issues between contracting parties. However, its principles are not sufficient to protect consumers during transactions on the Internet. Consumer protection in Iran gained statutory significance with the enactment of the Consumer Rights Protection Act (CRPA) in 2009. However, consumers performing online transactions can only rely on Iranian Electronic Commerce Law (IECL) 2004. In the following analysis, the current situation and evolution of the existing laws governing B2C contracts in Iran are scrutinised.

\section{CIVIL CODE 1936}

The civil law of any state is the principal foundation of its legal regime. The current contract law in Iran is the Civil Code in 1936. After Iran Commercial Code (ICC), the Civil Code is the second statute governing contract law in Iran. The drafters of the Civil Code were nominated from among the best lawmakers and legal theorists who are familiar with the laws of other countries. For example, they referred to the French Civil Code in 1807 which is known as Napoleonic Code in drafting the Iranian Civil Code. It is interesting to note that the French Civil Code referred to Islamic principles and to the literature of Jame Abbasi (written by Sheikh Bahaee who was a great Iranian Muslim scientist) (Agheli, 1991).

The development of a contract law framework and especially of the Civil Code in Iran happened after the collapse of the Ghajar Chain sovereignty. When the Pahlavid government (Reza Khan) came to power among its most important actions to void the rule of capitalisation included the enactment of the Civil Code. The Minister of Justice at that time (1915), who had a doctorate in Law and Political Science from a Swiss University individually summoned all of the authorised lawmakers throughout the country. He interviewed and negotiated with them and finally in 1917, a commission for creating a Civil Code whose members were mostly Muslim scholars was established (Agheli, 1940). At the beginning, the Minister of Justice who was educated in Europe wanted to employ foreign experts to draft the legislation but he eventually changed this plan after critical speeches by some of the Parliament members, especially Dr. Mosadiq who received his law education in Europe and later became Iran's Prime Minister. Then, the Minister of Justice became interested in using the opinions of the Islamic national experts in Fiq-al-Islam. The principles in the Civil Codes of Switzerland, France and Egypt were also applied in the drafting of the code. The Civil Code of Iran with 1335 Articles was enacted by the Iranian Parliament in 1936. The Iranian Civil Code is rare among legislation in Islamic countries as it contains many Islamic law principles. After 
the revolution of the Islamic Republic of Iran in 1976 and the passing of the new republic of Islamic Iranian constitution through a referendum all laws (according to Article 4) including the Civil Code must be adapted to full Islamic principles. Article 4 of the constitution states: All civil, penal, financial, economic, administrative, cultural, military, political and other laws and regulations must be based on Islamic criteria. This principle applies absolutely and generally to all articles of the constitution and to all other laws and regulations and the wise persons of the guardian council are judges in this matter. As a result, the Civil Code was revised and a few articles were omitted or changed.

The scope of the new Civil Code covers various aspects of contract law including essential principles of contracts: proposal, acceptance, consideration, free consent, capacity and intention to create a legal relation, type of contract, clauses in contract, breach, compensation and so on. Part II, Chapter I of the law from Article 183-265 is especially relevant to contracts, transactions and obligations. The Civil Code lays down the ground rules for the formation of a contract under the assumption that the contracting parties will carry out their consents and intentions (Naser, 2006). The terms however are left to the contracting parties to decide for themselves. The freedom given to the contracting parties conforms to the doctrine of freedom of contract but subject to the fact that the terms are entered into voluntarily, as stated in Article 190 for the validity of a contract the following conditions are essential:

- The intention and mutual consent of both parties to the contract

- The competence or capacity of both parties

- There must be a definite thing which forms the subject matter of the contract

- The cause of the contract must be lawful

The legislation conforms to the rights-based theories where contractual obligations are grounded in respect of individual rights and contract law gives legal force to such rights. There is a very important principle in Islam, especially for civil liability that is incorporated into the Civil Code: La Zarar which means that any aggrieved contractual party who suffers by the breach of a contract is entitled to receive, from the party who has broken the contract, compensation for any loss or damage caused to him thereby which naturally arose in the usual course of things from the breach or which the parties knew when they made the contract to be likely to result from the breach of it. In other words, the loss or damage must be compensated in any case no matter who is liable and why this loss has happened. This legislation has two areas of focus: first, the principle of will, meaning freedom of the parties wills in forming a contract and second, the principle of fault which insists on the liabilities out of the contract and the liability of damage compensation (Naser, 1990). As it is very difficult for the consumer to approve the fault of the producer and most of the consumer's online transactions are not follow freedom of will principle, these two theories cannot properly protect consumer's rights, at least in E-commerce transactions. The Civil Code of 1936 is a piece of general legislation that does not include provisions for consumer protection. B2C transactions necessitate social consideration, such as consumer welfare provisions in the making of the laws. The contract law should not stop short in its function as a facilitator: The general observation at the current era is the willingness to use the law to check some aspects of the content of a contract rather than simply the process of its formation has evolved (Weatherhill, 2005). New technologies in business especially the internet further increase the need for consumer protection and the Civil Code stops short of providing it.

Historically, the Iranian Civil Code and particularly the contract law, must change to keep pace with the velocity of technological and commercial changes. The legal landscape in Iran must adhere to the global legal development. As consumer interests and welfare become more discernible consumer protection needs to be reconciled with laws. The contract law must be modified by legislation to afford greater protection to consumers so that they can negotiate for themselves (Golding, 2004). Whether this change is possible through the enactment of a separate act or consolidation with other acts remains unanswered. It is submitted that the statement by Collins (2003) is relevant to the Iranian context. Collins (2003) says: the modern law of contract should be regulated in the light of social market where the core of law of contract should concern about; unjustifiable domination, the equivalence of exchange and the need to ensure cooperation. In this context, regulation is used as a generic term to describe any system of rules intended to govern the behaviour of its subject. The development of E-commerce which has increased the need for consumer protection makes it necessary that the Iranian Civil Code in 1936 be revised.

\section{COMMERCIAL CODE 1930}

One of the first pieces of legislation that was enacted in Iran was the Commercial Code (Mostafa, 2010). When this statute was enacted, electronic technology and E-commerce did not exist. The Iranian Commercial Code 
(ICC) 1930-revised in 1969 is a collection of rules governing commercial affairs and is an important statute in Iranian commercial law. This legislation was enacted based on the France Commercial Code in 1807. After $>76$ years, the ICC has remained unchanged. The revised form of the Commercial Code which contained 1000 Articles has been prepared by the Ministry of Justice and submitted to the specific commission of the Parliament. However, the parliament has not yet passed the code.

Although the ICC governs commercial transactions, bargaining regulations, joint stock companies, commercial documents and so on in 600 Articles the code has no provision for online transactions E-commerce or consumer legal protection. It is notable that the Electronic Commerce Law is attached to the ICC of course, it is not unusual that provisions of other E-commerce legislation for example, the US Uniform Commercial Code (UCC) are incorporated into the Iranian Commercial Code but it is argued that B2C E-commerce need a specific kind of law. It is proposed that in enacting suitable legislation for E-commerce lawmakers in Iran should consider legislation from other developed countries. Iran should consider, for example, the Electronic Commerce Models Law, UNCITRAL in 1996, the Model Law on Digital Signature Act in 2001 or the United Nations Convention on the Use of Electronic Communications in International Contracts in 2005 as a basis for enacting its laws, especially during the process of amending the ICC. Therefore, this traditional framework provides a picture of legislation that provides, at best, incomplete protection of consumer rights in new business contexts, namely E-commerce.

\section{CIVIL LIABПLITY CODE (CLC) 1960}

The Civil Liability Code (CLC) came into force in April 1960. Although, it is brief 16 Articles compared to the CC and ICC it provides a regulatory framework for the protection and legal recognition of Iran including consumers. Article 1 of this law states: Anyone who injures intentionally or due to his negligence, the life or health or property or freedom or prestige or commercial fame or any other right established for the individuals by virtue of law, as a result of which another one sustains materially or spiritually losses shall be liable to compensate the damages arising out of his action. This statute is focused on the grounds of fault in civil liability which is very difficult to prove in transactions. The tendency of the legislation then is greatly toward the rule of caveat emptor which means let the buyer beware. In other words, the buyer loses his right to sue the seller for breach of warranty if the buyer examined the goods before purchasing them. Although, the doctrine of caveat emptor may have been appropriate for transactions conducted in the conventional business market where products sold were agricultural products or components that were easily identified by the seller and buyer transactions through E-commerce are different. Some goods sold in E-commerce have defects that are difficult to identify and therefore, for some products that have safety repercussions, the principle of strict liability must be applied. In E-commerce therefore, the rule of caveat emptor should not be applied. As discussed before, the doctrine of freedom of contract which is contained in the Civil Code, allows flexibility to the parties to contract out implied conditions that are not conducive to them in E-commerce transactions. According to Naser (2008), the meaning of fault, like other social phenomena is changing. He proposed the following definitions for fault:

- Fault as a kind of punishment of unjust behaviour

- Fault as a device of protecting preferable rights

- Fault based on expedience and device

$\mathrm{He}$ then states that the modern Tort law (civil liability), especially in the case of producing and selling goods, tends to agree with the third definition. CLC is useful for consumer protection in terms of compensating the losses and damages to the consumers as a party of the contract but still with the application of the La Zarar (it ia an Islamic principle that says no loss or damage must be done without compansation and anybody who causes a loss or damage for others must compensate the victim. There are three elements to the liability in this case: loss or damage factor; the damageable act and causative relationship between the damage and loss factor (Ali, 2010)) principle and caveat emptor (let the buyer beware), the rights of the consumers in cyberspace cannot be attained completely. Finally, it is very difficult if not impossible for the consumer to establish the fault of the producer.

\section{CONSUMER RIGHTS PROTECTION ACT 2009}

The duty of preparing the act was entrusted to the previous organization of commercial deputy of planning and management in 1990, now the President Deputy Strategic Planning and Control (PDSPC). Up to 1993, there was no progress on the preparation of the act. Progress began in 1993. In preparing the act, 30 national and 15 foreign legal texts were consulted and compared to Iranian laws (Jaberi, 2008). Finally after 16 years (in 2009), the Consumer Rights Protection Act (CRPA) which contained 22 Articles and 15 Notices was passed by the parliament. The CRPA in 2009 contained the duties and liabilities of 
the producers, distributors, retailers and importers of goods and services, the government, ministry of justice and other ministries and organisations, all with the aim to protect consumer rights. Article 2 through 6 describe the liabilities of the producers. The duties of the government are mentioned in Article 21, 22, 25, 35 and 50 and the duty of the Ministry of Justice is described in Article 39, 40 and 42. The duties of other ministries and organisations are outlined in Article 4, 8, 20 and 52. With the enforcement of this act for the 1st time, NGOs and occupational organisations have been formed with the purpose of consumer protection. The establishment of the Consumers and Producers Protection Organization (CPPO) which is very active in protecting consumer rights was one of the outcomes of the enactment of this act (Article 21). An important action taken by this organisation is dedicating February 19 of each year as a National day of consumer protection rights. Its goal is to create awareness of consumers' rights among retailers and producers. The companies adopting the best strategies and measures for protecting consumers' rights will be awarded certification and other rewards. This legislation has solved some problems of contractual issues regarding consumer protection. Along with the legal protections of consumers by way of contractual duties and liabilities, the act also provides some criminal provisions in Chapter $\mathrm{V}$, under the category of Fines and Punishments, for parties that violate the law; thus, consumers are protected by criminal sanction.

According to Article 14 of the act, all disputes between producers and consumers will be referred to the Governmental Organization of Ta'zirat (GOT) (minor crimes). Article 15 has entrusted to the Ministry of Commerce (through its supervisors) a duty to control and supervise all functions of the individuals and legal persons under the jurisdiction of this act. Any wrong doings against consumers must be reported to the GOT, and the perpetrators will be prosecuted. Although, CRPA does not convey the same uncertainties of laws such as ICC, CC and CLC, it does not cover the rights of the consumer in cyberspace.

\section{ELECTRONIC COMMERCE LAW (ECL) 2004}

The Islamic republic of Iran Electronic Commerce Law (ECL) came into force in 2002 . The primary feature of this law is the assimilation of electronic contract formation into that of ordinary contracts and the grant of the legal recognition to contracts concluded through cyberspace and over the internet. This 2002 law is based on the UN Model Law. The United Nations Economic Commission for Europe (UN/ECE) as one of the regional economic commissions proposed an international common language known as the global standard of Electronic Data Interchange For Administration, Commerce and Transport (EDIFACT). For the expansion and promotion of this standard all over the world, the UN Center for Trade, facilitation and electronic business (UN/CEFACT) was established as one of the categories of UN/ECE. Following this international initiative, Asia-Pacific countries established the Asia-Pacific EDIFACT board which Iran joined in 1997. At the national level, under the supervision of the Iranian Ministry of Commerce, Deputy Minister for Planning and Economic Affairs established a national committee. This legal working group was assigned to prepare a draft of E-commerce legislation in the Autumn of 2000 and like other countries, Iran adopted the United Nations Commission on International Trade Law (UNCITRAL) model law as the basis for its electronic commerce law. The model law applies to any kind of information used in the context of commercial activities whether contractual or not. The provisions of the model agreement which deals with the formation of contracts are as follows:

- Validity and formation of the contract; Article 11

- Application of legal requirements to data messages; Article 5

- Admissibility in evidence of data messages; Article 9

- Processing and acknowledgement of receipt of data messages; Article 13-15

- Operational requirements for data messages; Article 10

- $\quad$ Effect, modification and severability; Article 4

Many countries have enacted laws on E-commerce transactions by modifying their legal provisions to suit the model law, enacting legislation governing online transactions, certification authorities and digital signatures and thereby creating a conducive environment for electronic commerce. In Iran, after some problematic negotiations about this draft, the Islamic Republic of Iran's Parliament passed the (IRI) Electronic Commerce Law (ECL) in 2004 (The flaws and strengths of this law will be scrutinised in the subsequent chapters). Apart from authenticating contract formation through electronic means and giving recognition to electronic data messages, the ECL in 2004 dedicated Section 1, Part 1 of Chapter 3 to consumer protection. However, there still exist some doubts and uncertainties about the law's applicability to consumer protection in the virtual arena. None of the legislation discussed above provides protection for consumers like the provisions in the ECL. 


\section{OTHER RELEVANT LEGISLATION}

Due to the enforcement of principle 123 of the Iranian Constitution, some other laws provide consumer protection, such as Car/Vehicle Consumers Protection Act No: $525 / 49525$ enacted by the Parliament in 2007 . The purpose of this act is to protect car consumers' rights, especially in terms of producer or retailer liabilities. According to Article 11, the Ministry of Mines and Industries is responsible for supervising and enforcing this act and for submitting a report to the Mines and Industries Commission of the Parliament every 6 months. Although, this act defines consumer and includes useful provisions regarding defective products that are not covered under the ECL, it nevertheless has no provision on consumer rights in online transactions. Another relevant act is the Computer Crime Act in 2009. It has played a decisive role in the indictment and prosecution of several cyber-activists and bloggers.

As technology, computer science and communication grow and develop, legislation must address the very important issue of computer crimes. The societies and countries that define these laws earlier than others can control and reduce crimes in cyberspace. Unfortunately, Iran with a population of about 75 million, 20 million of whom are $>23$ years old has a large population of computer and internet users but had no computer crime law until 2009. The first proposed Computer CrimeAct, enacted on 19 November 2008 was supported by 176 votes of the members of parliament.

The Computer Crimes Act (CCA) describes authority and jurisdiction which were not addressed in the ECL. The act has 5 parts and 55 sections and describes two kinds of punishments: jail, forfeiture or both. The CCA consists of two chapters: chapter 1 describes the elements of crime and punishment and chapter 2 describes the prosecution procedure. The following are some actions that $\mathrm{CCA}$ declares to be criminal offences:

- Crimes against data privacy and computer systems through unauthorised access to computers or data

- Crimes against the accuracy of data and computer fraud

- Destruction of or intervention in data and computer systems, such as wrongful communication of any number, code, password or other means of access to any computer

- Theft and fraud related to computers

- Crimes against charity and public ethics

- Crimes against rape dignity and spreading lies

- Criminal liability of the persons
This act focuses on crimes in cyberspace; it does not refer to consumer protection in E-commerce transactions. Currently, E-commerce is at the forefront in nations throughout the world and Iran is no exception. In every part of the world, legal regimes and new legislation are enacted to cater to the new mode of trading, i.e., E-commerce. Existing laws are re-evaluated and reassessed to assure that they fulfil their intended roles and address the many issues that arise in E-commerce. Consumer protection has caught global attention in the E-commerce arena. Laws are being revisited to ensure that consumer protection is not compromised in any circumstances. Infrastructures and means of promoting consumers' confidence in E-commerce are at the international forefront.

Therefore with consumer protection being at the forefront of international E-commerce law, the government in Iran must follow suit in expanding consumer protection beyond the Iran ECL. As consumer law is a part of shaping a society, consumer protection should be incorporated and expanded to other disparate areas in the cyber arena (Howells and Weatherhill, 1995). Meanwhile, when enacting new laws like the new Iran commercial code that is currently being deliberated consumer protection, especially in cyberspace, must be incorporated. In I.R. Iran, a legal framework that appropriately and coherently governs E-commerce with the central goal of consumer protection is desirable. In other words, the law should not be vague. Therefore, Iran's ECL must accord protection to consumers and must deter any antisocial behaviour and inculcate fair trade practices in E-commerce transactions. As in Iran, there is no special act for the sale of goods in general; a specific act to overcome the shortcomings of the absence of such an act and the existing laws that conform to the formation of sale of goods contracts over the internet whilst fortifying consumer protection is pertinent.

\section{CONCLUSION}

The contract law in Iran is in urgent need of reform to keep pace with the current innovation of ICT and incorporate global concerns while considering the Islamic perspective. The progress and development of E-commerce is dependent upon the comprehensiveness of the laws governing E-commerce transactions. Therefore, legislation is an important way to overcome challenges in the information technology arena. Consumer protection should not be addressed piecemeal; instead, contractual principles protecting consumers should be instilled under a specific law, namely the consumer contract law. Iran should not wait for disputes to arise to 
assess the suitability of its laws for handling E-commerce issues. Instead, it should equip itself with modern infrastructure as it is lagging behind in adapting to technological advancements, especially in the areas of online contract formation and consumer protection. The researcher is of the opinion that legislative measures in terms of a specific act are suited to the modus operandi of E-commerce contracts and would remove any legal obstacles or impediments to the development of electronic commerce and create a secure legal environment for consumers.

\section{REFERENCES}

Agheli, B., 1940. Davar and Ministry of Justice. Elmi Publication, Tehran, Iran.

Agheli, B., 1991. Iran History Days Counting. Goftar Publication, Tehran, Iran.

Ali, Z.A.D., 2010. The Interpretation of Lomeat-AlDameshghiye. Kashan Publication, Tehran, Iran.

Brian, F., 2006. Cyber Law. Cromwell Press, Trowbridge, Wiltshire, UK.

Chand, H., 1999. Modern Jurisprudence. International Law Book, Malaysia.

Collins, H., 2003. The Law of Contract. 4th Edn., Lexis Nexis, UK.

Forder, J. and P. Quirk, 1995. Electronic Commerce and the Law. Wiley, Australia.

Freeman, M.D.A. and B.D.L.L. Hampstead, 2008. Lloyd's Introduction to Jurisprudence. 8th Edn., Sweet and Maxwell, London, ISBN: 9780421907904, Pages: 1600.

Gillette, C.P., 2005. Pre-approved contracts for Internet commerce. Hous. L. Rev., 42: 975-979.

Golding, J., 2004. Consumer protection, the nation-state, law, globalization and democracy. J. Int. Comparative Law, Vol. 2
Howells, G.G. and S. Weatherhill, 1995. A Consumer Protection Law. Cambridge University Press, Cambridge, UK.

Jaberi, E., 2008. Consumer Rights. Farda Publication, Esfehan, Iran.

Kohl, U., 1999. Legal reasoning and legal change in the age of the internet-why the ground rules are still valid. Int. J. Law Inform. Technol., 7: 123-151.

Llewellyn, K.N., 1939. Across sales on horseback. Harward Law Rev., 52: 725-727.

Lynch, E., 1997. Protecting Consumers in the Cybermarket. OECD, Paris, France, pp: 11-15.

McKendrick, E. and L. Gullifer, 2000. Sale of Goods. LLP Professional Publishing, London, ISBN: 9781859783054, Pages: 920.

Moghadasi, A., 2008. Iran e-commerce challenges. New J. Econ. Bus., 6: 22-56.

Mostafa, A., 2010. The importance of considering ecommerce in reforming the commercial code in Iran. Tehran, Electronic Newspaper of Consumers, Producers Protection Organization (CPPO).

Naser, K., 1990. Definite Contracts. Vol. 1, Beh Nashr Publication, Tehran, Iran.

Naser, K., 2006. Civil Code at the New Legal Dicipline. Mizan Publication, Tehran, Iran.

Naser, K., 2008. The innovation of fault definition in civil liability. Law Political Sci. J., 39: 189-214.

Overby, A.B., 2001. An institutional analysis of consumer law. Vanderbilt J. Transnational Law, 34: 1219-1291.

Ponser, E.A., 2003. Economic analysis of contract law after three decades: Success or failure?. Yale Law J., 112: 829-880.

Ramsay, I., 2007. Consumer Law and Policy. Hart Publishing, Portland, USA.

Weatherhill, A.S., 2005. EU Consumer Law and Policy. Edward Elgar Publishing Ltd., Cheltenham, UK. 